\title{
Lung function, breathing pattern, and gas exchange in interstitial lung disease
}

\author{
S Javaheri, L Sicilian
}

\begin{abstract}
Background The aim of this study was to determine the relation between the severity of abnormalities in ventilatory function tests and tidal breathing pattern and gas exchange indices in interstitial lung disease.
\end{abstract}

Methods Pulmonary function, ventilation, carbon dioxide production, oxygen consumption, arterial blood gas tensions, and $\mathrm{pH}$ were measured during resting steady state conditions in 60 patients with proved interstitial lung disease. Patients were categorised by forced vital capacity (FVC) (percentage of predicted values) as having a mild, moderate, or severe restrictive defect with means (SD) of $71 \%$ $(4 \%), 57 \%(4 \%)$, and $41 \%(7 \%)$ of predicted values, respectively.

Results FVC varied from $29 \%$ to $79 \%$ of predicted values and from 0.991 to 4.321 . The two measurements of FVC correlated strongly with most static lung volumes and with transfer factor for carbon monoxide. Mean respiratory rates (per minute) and tidal volumes ( $\mathrm{ml}$ ) were 17 (4) and 484 (131), 20 (4) and 460 (139), and 23 (5) and 377 (109) in mild, moderate, and severe restrictive defects, respectively. FVC correlated negatively with respiratory rate and positively with tidal volume. Arterial carbon dioxide tension ranged from 30 to $49 \mathrm{~mm} \mathrm{Hg}$; only two patients were hypercapnic. Mean arterial oxygen tensions were not significantly different among the three groups, and there were no significant correlations between forced expiratory volume in one second or FVC and arterial carbon dioxide tension or carbon dioxide production. Conclusion Low values of FVC were associated with increased respiratory rate and decreased tidal volume; this pattern of breathing mimics external elastic loading, suggesting that mechanoreceptors may contribute to the rapid and shallow pattern of breathing in interstitial lung disease. Hypercapnia seems to be rare in interstitial lung disease even when functional impairment is severe and tidal volume is small. The increased respiratory rate is important in maintaining adequate ventilation. In the face of a severe restrictive defect carbon dioxide production did not increase, which also contributed to the maintenance of eucapnia.
The relation between lung function test values, breathing pattern, and gas exchange has been studied in patients with chronic obstructive lung disease. Carbon dioxide retention in these patients is usually associated with a forced expiratory volume in one second $\left(F E V_{1}\right)$ of less than 1.0 litre $^{1-4}$, and the same is true in asthma. ${ }^{5-7}$

The pattern of breathing may contribute to carbon dioxide retention. Hypercapnic patients with chronic obstructive lung disease breathe faster and more shallowly than eucapnic patients, ${ }^{48}$ causing an increase in the ratio of dead space to tidal volume (VD/VT) and in dead space ventilation (VD) with a decrease in alveolar ventilation ( $\left.\dot{V}_{A}\right)$; this results in hypercapnia.

Few studies have examined the pattern of breathing in diffuse interstitial lung disease. ${ }^{9-13}$ Although it is commonly believed that patients with interstitial lung disease breathe more rapidly and shallowly than normal subjects, previous studies have reported considerable variation in both breathing frequency and tidal volume. In the original study of Lourenco et al, for example, the respiratory rate varied from 13 to 40 breaths/min, and tidal volume from 306 to $612 \mathrm{ml}^{.9}$ In a more recent study Renzi et al showed that changes in respiratory rate and tidal volume were related to stiffness (elastance) of the lungs in 12 patients with interstitial lung disease and suggested that variations in breathing pattern were probably related to differences in the severity of the disease. ${ }^{13}$

The main aim of this study was to determine the relation between the pattern of breathing and gas exchange during steady state breathing at rest and ventilatory lung function in a large group of carefully selected patients with proved interstitial lung disease.

\section{Methods}

We reviewed the results of pulmonary function tests in patients with a restrictive lung defect (forced vital capacity $<80 \%$ predicted) and an established diagnosis of interstitial lung disease. The patients were referred for diagnosis and treatment of interstitial lung disease. The diagnosis was made by open lung biopsy or from the presence of specific historical findings such as occupational exposure. Methods of diagnosis have been reported in detail. ${ }^{14} 15$

We excluded all patients with (a) a ratio of $\mathrm{FEV}_{1}$ to forced vital capacity (FVC) of $<75 \%$; (b) neuromuscular disorders; (c) kyphoscoliosis, (d) pulmonary emboli; (e) lung car- 
cinoma; $(f)$ acute respiratory alkalosis or metabolic acidosis or alkalosis ${ }^{16}$; and $(g)$ obesity. Obesity was defined as a body mass index (body weight $(\mathrm{kg}) /(\text { height }(\mathrm{m}))^{2}$ ) greater than 27.8 and 27.3 in men and women, respectively. ${ }^{18}$ Finally, the respiratory exchange ratio had to be $0.83(0.05)$.

\section{MEASUREMENT OF LUNG FUNCTION}

The technical details, methods of analysis, precautions, and calibrations used in our laboratory have been outlined previously. ${ }^{19}$

Spirometric measurements were obtained with a Stead-Wells spirometer while the patient was seated. Functional residual capacity (FRC) was measured by helium equilibration, and residual volume (RV) and total lung capacity (TLC) were calculated.

The single breath carbon monoxide transfer factor (TLCO) was measured as described..$^{20}$ Ventilation and arterial blood gas tensions and $\mathrm{pH}$ were determined with the patient supine and comfortable. An arterial cannula was placed in the radial or brachial artery. The patient then breathed through a mouthpiece connected to a two way valve (Hans-Rudolf, Kansas City, Missouri) into a Douglas bag. The respiratory rate and tidal carbon dioxide tension were monitored with an infrared analyser or a mass spectrometer (1100 Medical Gas Analyzer, Perkin Elmer, Pomona, California). When end tidal carbon dioxide was stable, after an initial wash out, expired air was collected for two minutes. The volume of expired air was determined in a Tissot spirometer and oxygen and carbon dioxide concentrations in expired air by a mass spectrometer. An arterial blood sample was obtained for determination of arterial blood gas tensions and $\mathrm{pH}$. A calculator was used to calculate plasma bicarbonate concentration (Severinghaus Calculator, Radiometer, Copenhagen).

From these measurements, minute ventilation $\left(\dot{V}_{E}\right)$, respiratory rate, tidal volume, dead space (VD), alveolar ventilation ( $\left.\dot{V}_{A}\right)$, oxygen consumption $\left(\mathrm{V}_{2}\right)$, carbon dioxide production $\left(\dot{\mathrm{V}} \mathrm{CO}_{2}\right)$, and respiratory exchange ratio were calculated.

Normal values for the spirometric data were taken from Kory et $a l_{,}{ }^{21}$ and regression equations for TLCo from Gaensler and Smith. ${ }^{20}$

\section{ANALYSIS}

Patients were divided into three groups on the basis of the FVC representing mild, moderate, and severe restrictive defect: $79 \%$ to $>65 \%$, $65 \%$ to $>50 \%$, and $\leqslant 50 \%$ of predicted values, respectively. The groups were compared by analysis of variance and multiple $t$ tests adjusted by the Bonferroni method. Patients with moderate (group 2) and severe (group 3) restrictive defects were compared with those having a mild restrictive defect (group 1) (two comparisons), and $p \leqslant 0.025$ was considered to be significant. Data are presented as means with standard deviations in parentheses.

We also determined Pearson linear correlations for certain variables and then considered a p value below 0.05 to be significant. The SAS computer software of the University of Cincinnati was used for the calculations.

\section{Results}

Sixty patients met the criteria, with 27,18 , and 15 in groups 1,2 , and 3 , respectively. The major diagnoses were idiopathic pulmonary fibrosis (25 patients), sarcoidosis (11), asbestosis (eight), collagen vascular disease (six), berylliosis and silicosis (three), and chronic eosinophilic pneumonia and eosinophilic granuloma (four). The distribution of disease was similar among the three groups.

Morphometric data are shown in table 1. Although mean values for height, weight, and body surface area were lower in group 3 than in groups 1 and 2 the differences were not significant.

FVC ranged from $79 \%$ to $29 \%$ of predicted values. There were significant differences in most spirometric and lung volume measurements between the groups (table 2). FVC, $F_{E V}$, and TLC were significantly lower in groups 2 and 3 when compared with group 1 whether expressed as percentages of predicted values or as absolute values (table 2 ). The only measurements that did not differ significantly between the three groups were small differences in residual volume (RV) (and RV percentages of predicted values) and $\mathrm{FEV}_{1}$ to $\mathrm{FVC}$ ratio.

Although arterial carbon dioxide tension $\left(\mathrm{PaCO}_{2}\right)$ varied from $30 \mathrm{~mm} \mathrm{Hg}(4.0 \mathrm{kPa})$ to $49 \mathrm{~mm} \mathrm{Hg}(6.5 \mathrm{kPa})$ in individual patients, mean values of $\mathrm{PaCO}_{2}$ (table 3) did not differ between the three groups. Mean values for carbon dioxide production and oxygen consumption (per surface area) also did not differ significantly in the three groups (table 3 ).

Although minute and alveolar ventilation (per surface area) did not differ between the three groups (table 3 ), breathing pattern varied considerably with a significant and progressive rise in respiratory rate and a progressive fall in tidal volume.

\section{CORRELATIONS BETWEEN VARIABLES}

FVC correlated significantly with other lung volumes, the highest correlation occurring with inspiratory capacity and TLC, and the lowest with RV (table 4). Similar correlations were

Table 1 Demographic data on three groups of patients with interstitial lung diseases categorised according to percentage of predicted forced vital capacity. Values are means (SD)

\begin{tabular}{|c|c|c|c|c|c|}
\hline & Age (years) & Height $(\mathrm{cm})$ & Weight (kg) & $B S A\left(m^{2}\right)$ & $B M I\left(\mathrm{~kg} / \mathrm{m}^{2}\right)$ \\
\hline $\begin{array}{l}\text { Group } 1(n=27) \\
\text { Group } 2(n=18) \\
\text { Group } 3(n=15)\end{array}$ & $\begin{array}{l}46 \cdot 2(17 \cdot 2) \\
47 \cdot 2(17 \cdot 1) \\
39 \cdot 7(17 \cdot 0)\end{array}$ & $\begin{array}{l}170.9(11 \cdot 2) \\
167 \cdot 1(9.9) \\
165.4(10.0)\end{array}$ & $\begin{array}{l}70.0(13.4) \\
65 \cdot 1(10.5) \\
59.7(13.0)\end{array}$ & $\begin{array}{l}1.81(0 \cdot 22) \\
1.73(0 \cdot 18) \\
1.65(0.21)\end{array}$ & $\begin{array}{l}23.9(3.9) \\
23.2(2 \cdot 5) \\
21.7(3.0)\end{array}$ \\
\hline
\end{tabular}

BSA = body surface area BMI = body mass index 
Table 2 Mean (SD) lung volumes in three groups of patients with interstitial lung diseases categorised according to percentage of predicted forced vital capacity

\begin{tabular}{|c|c|c|c|}
\hline Lung volume & $\begin{array}{l}\text { Group 1 } \\
(n=27)\end{array}$ & $\begin{array}{l}\text { Group 2 } \\
(n=18)\end{array}$ & $\begin{array}{l}\text { Group } 3 \\
(n=15)\end{array}$ \\
\hline 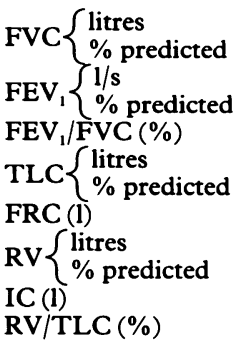 & $\begin{array}{c}2 \cdot 88(0 \cdot 76) \\
71 \quad(4) \\
2 \cdot 42(0 \cdot 68) \\
73 \quad(8) \\
84 \quad(6) \\
4 \cdot 31(1 \cdot 01) \\
91 \quad(11) \\
2 \cdot 18(0 \cdot 60) \\
1 \cdot 30(0 \cdot 44) \\
108 \quad(31) \\
2 \cdot 12(0 \cdot 69) \\
31 \quad(9)\end{array}$ & $\begin{array}{c}2 \cdot 17(0.53)^{\star} \\
57(5)^{\star} \\
1.82(0.42)^{\star} \\
59(8)^{\star} \\
84(5) \\
3 \cdot 38(0 \cdot 86)^{\star} \\
74(13)^{\star} \\
1 \cdot 86(0.53) \\
1 \cdot 17(0.41) \\
103(43) \\
1.52(0.59)^{\star} \\
35(10)\end{array}$ & $\begin{array}{l}1.54(0.32)^{\star} \\
41(7)^{\star} \\
1.35(0.31)^{\star} \\
41 \quad(7)^{\star} \\
87(9) \\
2.54(0.39)^{\star} \\
57(12)^{\star} \\
1.48(0.39)^{\star} \\
0.96(0.40) \\
88(36) \\
1.06(0.34)^{\star} \\
38(12)\end{array}$ \\
\hline
\end{tabular}

${ }^{\star} \mathrm{p} \leqslant 0.025 v$ group 1 .

FVC = forced vital capacity; TLC $=$ total lung capacity; FRC $=$ functional residual capacity; $\mathbf{R V}=$ residual volume; $\mathrm{IC}=$ inspiratory capacity.

Table 3 Mean (SD) gas exchange and ventilation values in three groups of patients with interstitial lung diseases categorised according to percentage of predicted forced vital capacity

\begin{tabular}{|c|c|c|c|c|c|c|}
\hline \multirow{8}{*}{$\begin{array}{l}\mathrm{PaO}_{2}(\mathrm{~mm} \mathrm{Hg}) \\
\mathrm{PaCO}_{2}(\mathrm{~mm} \mathrm{Hg}) \\
{\left[\mathrm{H}^{+}\right]\left(\mathrm{nEq}^{\prime} \mathrm{l}\right)} \\
{\left[\mathrm{HCO}^{-}\right](\mathrm{mEq} / \mathrm{l})} \\
\mathrm{Vo}_{2} / \mathrm{BSA}\left(\mathrm{ml} / \mathrm{min} / \mathrm{m}^{2}\right) \\
\mathrm{Vo}_{2} / \mathrm{BSA}\left(\mathrm{ml} / \mathrm{min} / \mathrm{m}^{2}\right) \\
\mathrm{RER}\end{array}$} & \multicolumn{2}{|c|}{ Group 1} & \multicolumn{2}{|c|}{ Group 2} & \multicolumn{2}{|c|}{ Group 3} \\
\hline & 76 & (12) & 71 & (14) & 74 & (17) \\
\hline & 37 & (4) & 36 & (3) & 39 & (5) \\
\hline & $39 \cdot 0$ & $(2 \cdot 4)$ & $37 \cdot 6$ & $(1 \cdot 8)$ & $38 \cdot 0$ & $(2 \cdot 0)$ \\
\hline & 23 & (2) & 24 & (2) & 25 & (3) \\
\hline & 135 & (17) & 147 & (28) & 142 & (21) \\
\hline & 109 & (14) & 120 & (24) & 115 & (21) \\
\hline & 0.81 & $(0.03)$ & 0.82 & $(0.04)$ & 0.81 & $(0.04)$ \\
\hline $\mathrm{T},\{(\mathrm{ml} / \mathrm{min} / \mathrm{mmHg})$ & 17 & (7) & 14 & (7) & 12 & (6) \\
\hline 1 LCO $(\%$ predicted $)$ & 64 & (20) & 54 & (26) & 49 & $(34)^{\star}$ \\
\hline $\mathbf{R} \mathbf{R}(\min )$ & 17 & $(4)$ & 20 & $(4)^{\star \star}$ & 23 & $(5)^{\star \star \star}$ \\
\hline VT $(\mathrm{ml})$ & 484 & (131) & 460 & (139) & 377 & $(109)^{\star \star \star}$ \\
\hline VD (ml/kg) & $2 \cdot 4$ & $(1 \cdot 1)$ & $2 \cdot 7$ & $(1 \cdot 2)$ & $2 \cdot 7$ & $(0 \cdot 8)$ \\
\hline VD/VT $(\%)$ & 34 & (12) & 37 & (10) & 42 & (7) \\
\hline$\dot{V} \mathrm{E} / \mathrm{BSA}\left(\mathrm{l} / \mathrm{min} / \mathrm{m}^{2}\right)$ & $4 \cdot 4$ & $(0 \cdot 8)$ & $5 \cdot 2$ & $(1 \cdot 5)$ & $5 \cdot 1$ & $(0.9)$ \\
\hline$\dot{\mathrm{V}} \mathbf{A} / \mathbf{B S A}\left(\mathrm{l} / \mathrm{min} / \mathrm{m}^{2}\right)$ & $2 \cdot 8$ & $(0 \cdot 3)$ & $3 \cdot 2$ & $(0.4)$ & $3 \cdot 0$ & $(0 \cdot 4)$ \\
\hline
\end{tabular}

${ }^{\star} \mathrm{p} \leqslant 0.025 ;^{\star \star} \mathrm{p} \leqslant 0.017 ;^{\star \star \star} \mathrm{p} \leqslant 0.01$ (all $v$ group 1 ).

BSA = body surface area; $\dot{\mathrm{V}} \mathrm{O}_{2}=$ oxygen consumption; $\dot{\mathrm{V}} \mathrm{CO}_{2}=$ carbon dioxide production; TLCO = transfer factor for carbon monoxide; RER = respiratory exchange ratio; $\dot{V}_{E}=$ minute ventilation; $\dot{V}_{A}=$ alveolar ventilation. $\dot{V}_{o_{2}}, \dot{V}_{C_{2}}$, and $T_{L C O}$ are at STPD. Ventilatory values are at BTPS.

Conversion to SI unit: $1 \mathrm{~mm} \mathrm{Hg} \approx 0.133 \mathrm{kPa}$.

found between FVC as a percentage of predicted values and other predicted values (data not shown).

Both FVC and FVC \% predicted correlated with respiratory rate and tidal volume (figures 1 and 2).

The correlations between both $\mathrm{PaCO}_{2}$ and $\mathrm{PaO}_{2}$ and other variables are summarised in table 5. In addition, there were no significant correlations between $\mathrm{PaCO}_{2}$ and $\mathrm{VD}, \mathrm{VD} / \mathrm{VT}$ ratio, body weight, $\mathrm{FEV}_{1}, \mathrm{FEV}_{1} \%$ predicted, FVC, and FVC \% predicted. However, $\mathrm{PaO}_{2}$ correlated significantly with FVC $(r=0.28$, $\mathrm{p}=0.035)$ and TLCo $(\mathrm{r}=0.39, \mathrm{p}=0.003)$.

There was no correlation between $\dot{\mathrm{Vo}}_{2}$ and $\dot{\mathrm{V}} \mathrm{CO}_{2}$ (or $\dot{\mathrm{VO}}_{2}$ and $\dot{\mathrm{V}} \mathrm{CO}_{2}$ in relation to body surface area) and $\mathrm{FEV}_{1}, \mathrm{FVC}, \mathrm{FEV}_{1} / \mathrm{FVC}$ ratio, $R V / T L C$ ratio, or their respective predicted values.

\section{Discussion}

To obtain reliable measures of the pattern of breathing, ventilation, and arterial blood gas tensions in patients with pulmonary disease, steady state criteria must be met. ${ }^{4}$ Applying a noseclip and mouthpiece ${ }^{22}$ and sampling arterial blood may change the pattern of breathing. In our study several precautions were taken to ensure the presence of a steady state. Measurements of ventilation were started only after the patient had already breathed for several minutes through the mouthpiece and shown stable end tidal carbon dioxide concentrations. Normal values of respiratory exchange ratio were required. Arterial blood was obtained through an indwelling cannula, and the strong linear correlation $(r=0.85)$ between $\mathrm{PaCO}_{2}$ and bicarbonate concentration with a slope of 0.58 indicates that changes in $\mathrm{PaCO}_{2}$ were long term.

We studied 60 patients, 11 of whom had a severe restrictive defect with an FVC below 1.5 1. Among these 60 patients two had a high $\mathrm{PaCO}_{2}$ of $44 \mathrm{~mm} \mathrm{Hg}(5.9 \mathrm{kPa})$, one had $45 \mathrm{~mm} \mathrm{Hg}(6.0 \mathrm{kPa})$ and one $49 \mathrm{~mm} \mathrm{Hg}$ $(6.5 \mathrm{kPa})$. Chronic hypercapnia therefore seems to be rare in ambulatory patients with interstitial lung disease. Severe $\dot{V} / \dot{Q}$ mismatch impairs carbon dioxide elimination, ${ }^{23} 24$ but our patients were generally capable of increasing their minute ventilation and, hence, alveolar ventilation, to prevent hypercapnia. In addition, $\mathrm{V} \mathrm{CO}_{2}$ (table 2), another determinant of $\mathrm{PaCO}_{2}$, remained relatively constant even in patients with marked impairment of FVC.

Several factos probably help to maintain $\dot{V E}_{E}$ and $\dot{V}_{A}$ in these patients. One factor, not looked at in this study, is the low to mid position of the chest wall in patients with a low FVC. This position places the inspiratory muscles at a mechanical advantage. Two factors identified in this study were the low values of $\mathrm{PaO}_{2}$ and high respiratory rate. We found a significant negative correlation between $\mathrm{PaO}_{2}$ and minute ventilation (table 5 ), perhaps suggesting that hypoxaemia may augment resting ventilation in patients with more severe interstitial lung disease. A major factor, however, contributing to maintenance of ventilation was the increase in respiratory rate.

Our results show that in interstitial lung disease breathing pattern changes, lower values of FVC being associated with an increased respiratory rate and decreased tidal volume. Previous studies have reported considerable variation in respiratory rate and tidal volume in patients with interstitial lung disease, though the number of patients was usually small and the variation reported is probably related to the differences in severity of restriction between studies. In our study respiratory rate varied

Table 4 Pearson correlations of forced vital capacity versus other lung function values in interstitial lung disease

\begin{tabular}{lllllllll}
\hline FEV & $F E V_{1} / F V C$ & $T L C$ & $R V$ & $R V / T L C$ & $I C$ & ERV & FRC \\
\hline r & 0.98 & -0.2 & 0.90 & 0.26 & -0.52 & 0.89 & 0.53 & 0.58 \\
p & 0.0001 & 0.2 & 0.0001 & 0.04 & 0.0001 & 0.0001 & 0.0001 & 0.0001 \\
\hline
\end{tabular}

ERV = expiratory reserve volume; TLCO = single breath transfer factor for carbon monoxide; other abbreviations as in table 3. 
Table 5 Pearson correlations of $\mathrm{PaCO}_{2}$ and $\mathrm{PaO}_{2}$ versus results of ventilatory and gas exchange tests in interstitial lung disease

\begin{tabular}{|c|c|c|c|c|c|c|c|c|}
\hline & $\begin{array}{l}\dot{V E} / B S A \\
\left(l / \min / \mathrm{m}^{2}\right)\end{array}$ & $\begin{array}{l}\dot{V}_{A} / B S A \\
\left(l / \min / \mathrm{m}^{2}\right)\end{array}$ & $\begin{array}{l}R R \\
(\min )\end{array}$ & $\begin{array}{l}V T \\
(m l)\end{array}$ & $\begin{array}{l}\dot{V} \mathrm{CO}_{2} / B S A \\
\left(\mathrm{l} / \mathrm{min} / \mathrm{m}^{2}\right)\end{array}$ & $\begin{array}{l}{\left[\mathrm{HCO}_{3}^{-}\right]} \\
(\mathrm{mEq} / \mathrm{l})\end{array}$ & $\begin{array}{l}{\left[\mathrm{H}^{+}\right]} \\
(n E q / l)\end{array}$ & $\begin{array}{l}T L C O \\
(\mathrm{ml} / \mathrm{min} / \mathrm{mmHg})\end{array}$ \\
\hline $\begin{array}{l}\mathbf{r} \\
\mathbf{p}\end{array}$ & $\begin{array}{r}-0.2 \\
0.1\end{array}$ & $\begin{array}{r}-0.29 \\
0.02\end{array}$ & $\begin{array}{r}-0 \cdot 2 \\
0 \cdot 2\end{array}$ & $\begin{array}{l}0 \cdot 1 \\
0 \cdot 4\end{array}$ & $\begin{array}{l}0 \cdot 2 \\
0 \cdot 2\end{array}$ & $\begin{array}{l}0.85 \\
0.0001\end{array}$ & $\begin{array}{l}0 \cdot 1 \\
0 \cdot 4\end{array}$ & $\begin{array}{l}0 \cdot 1 \\
0 \cdot 2\end{array}$ \\
\hline $\begin{array}{l}\mathbf{r} \\
\mathrm{p}\end{array}$ & $\begin{array}{c}-0.41 \\
0.001\end{array}$ & $\begin{array}{r}-0.1 \\
0.4\end{array}$ & $\begin{array}{r}-0.04 \\
0.74\end{array}$ & $\begin{array}{r}-0.27 \\
0.04\end{array}$ & $\begin{array}{r}-0 \cdot 2 \\
0 \cdot 2\end{array}$ & $\begin{array}{r}-0.1 \\
0.3\end{array}$ & $\begin{array}{l}0.01 \\
0.9\end{array}$ & $\begin{array}{l}0.39 \\
0.003\end{array}$ \\
\hline
\end{tabular}

$\dot{V} \mathbf{E}=$ minute ventilation; $\dot{V}_{A}=$ alveolar ventilation; $B S A=$ body surface area; $R R=$ respiratory rate; VT $=$ tidal volume; TLCo $=$ single breath transfer factor for carbon monoxide; $\mathrm{VCO}_{2}=$ carbon dioxide.

from eight to 33 per minute and tidal volume from 214 to $829 \mathrm{ml}$ in individual subjects and were often normal in patients with minimally abnormal FVC values (group 1). When rapid and shallow breathing is clinically obvious the patients characteristically have severe mechanical impairment.

The mechanisms mediating the rapid and shallow breathing in interstitial lung disease

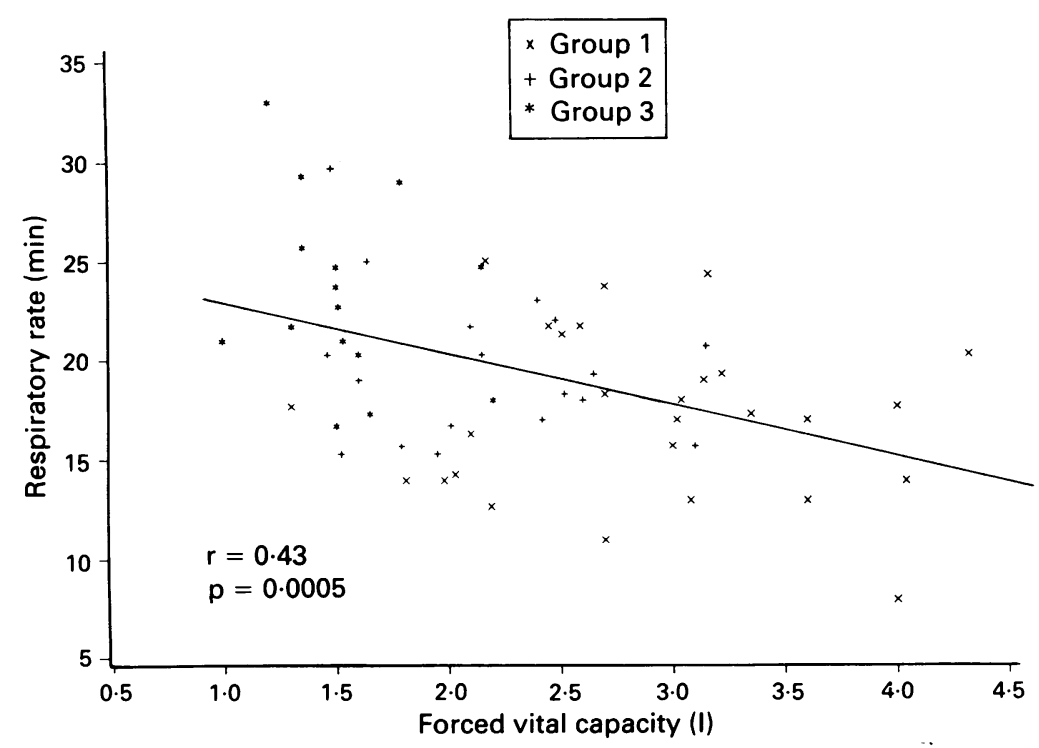

Figure 1 Linear regression between forced vital capacity (FVC) and respiratory rate (RR).

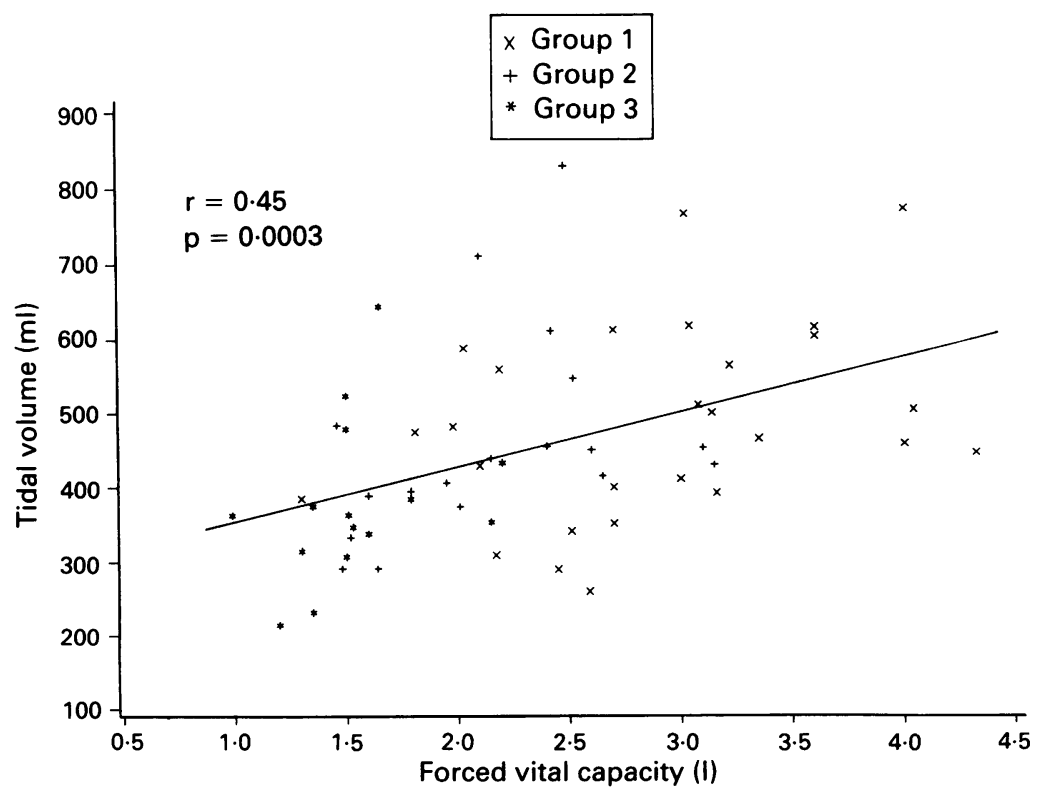

Figure 2 Linear regression between forced vital capacity and tidal volume (VT). have been reviewed by several authors. ${ }^{25-28}$ They include the mechanical effects of increased lung elastance, perceived as increasing load by mechanoreceptors, and stimulation of intrapulmonary receptors-for example, rapidly adapting and $\mathrm{J}$ receptors.

External elastic loading of the respiratory system (breathing from a rigid chamber) has been used to study the role of mechanoreceptors in determining the pattern of breathing. External elastic loading is thought to represent the mechanical analogue of diffuse interstitial lung disease (internal elastic loading). Several studies have shown that normal subjects breathe shallowly and rapidly in response to an external load and that respiratory rate increases progressively and tidal volume falls as the magnitude of the external elastic load increases. $^{29-33}$ Our results show similar differences in the pattern of breathing in relation to lower values of FVC, which are consistent with those of studies on external elastic load.

Intrinsic elastic loading does not seem to account fully for the pattern of breathing in our patients. Despite a significant correlation between FVC and respiratory rate and tidal volume, the results show a considerable scatter. Several factors, such as stimulation of both mechanoreceptors and other intrapulmonary receptors, ${ }^{25-28}$ may have contributed to the pattern of breathing we observed. Intrapulmonary receptors may be stimulated by inflammatory mediators ${ }^{25-26}$ released from cells which accumulate in the lung parenchyma of patients with interstitial lung disease ${ }^{34}$ and studies by Guz et al in humans ${ }^{27} 28$ and by Phillipson et al in $\operatorname{dogs}^{35}$ indicate that stimulation of these receptors contributes to tachypnoea.

Irrespective of the mechanisms involved, in the face of severe interstitial lung disease a raised respiratory rate is important in maintaining adequate ventilation because tidal volume is small and gas exchange impaired. This pattern of breathing is appropriate to the mechanical properties of the respiratory system in interstitial lung disease. ${ }^{36}$ It enables patients to maintain ventilation with a smaller inspiratory muscle force and less mechanical work per breath ${ }^{36}$ which should minimise the work of breathing. Mean values of $\mathrm{VCO}_{2}$ and $\mathrm{VO}_{2}$ in relation to body surface area did not differ in our three groups of patients. Indices of metabolic rate did not correlate with ventilatory impairment in contrast to the findings in patients with chronic obstructive lung disease. $^{37}$ In normal subjects the increase in 
oxygen consumption caused by an added inspiratory external elastic load is less than that seen with a resistive load, ${ }^{38}$ an effect attributed to preferential recruitment of faster and less efficient muscle fibres during breathing with a resistive load.

From our results in 60 patients with interstitial lung disease we draw several conclusions. With respect to gas exchange, FVC correlates with impairment in TLCO more strongly than with hypoxaemia. Changes in $\mathrm{PaCO}_{2}$ do not relate to severity of impairment of any spirometric values - for example, $\mathrm{FEV}_{1}$ or FVC in absolute terms or as percentage of predicted values. Low values of FVC are associated with higher respiratory rates and lower tidal volumes; in the face of severe impairment in gas exchange, changes in respiratory rate are important for maintaining adequate ventilation and eucapnia. This pattern of breathing minimises the work of breathing, and carbon dioxide production and oxygen consumption remain relatively constant even when mechanical impairment is severe. The lack of a rise in carbon dioxide production in the face of increasing functional impairment (increasing mechanical and gas exchange defects) is important in preventing the development of hypercapnia in interstitial lung disease.

We thank Dr E A Gaensler for allowing us to report the data collected in his laboratory. The authors also thank Mrs Saundra K Eversole for her excellent secretarial help, Mr Robert J Mohrman for his careful review of the manuscript, and Dr P Gartside for his help in the statistical analysis.

1 Burrows B, Sakesena FB, Diener CF. Carbon dioxide tension and ventilatory mechanics in chronic obstructive pulmonary disease. Ann Intern Med 1966;65:685-700

2 Howell JBL. Breathlessness in pulmonary disease. In Howell JBL, Campbell EJM, eds. Breathlessness. Oxford: Blackwell Scientific Publications, 1966;165-77.

3 Javaheri S. Premorbid hypercapnic ventilatory response and $\mathrm{PaCO}_{2}$ in emphysema. Pflugers Arch 1987;408:S29.

4 Javaheri S, Blum J, Kazemi H. Pattern of breathing and carbon dioxide retention in chronic obstructive lung disease. Am J Med 1982;71:228-34.

5 McFadden ER Jr, Lyons HA. Arterial-blood gas tension in asthma. N Engl J Med 1968;278:1027-32.

6 Rebuck AS, Read J. Assessment and management of severe asthma. Am J Med 1971;51:788-98.

7 Kelsen SG, Kelsen DP, Fleegler BF, Jones RC, Rodman T. Emergency room assessment and treatment of patients with acute asthma. Am J Med 1978;64:622-8.

8 Sorli J, Grassino A, Lorange G, Milic-Emili J. Control of breathing in patients with chronic obstructive lung disease. Clinical Science and Molecular Medicine 1978;54:295-304.

9 Lourenco RV, Turino GM, Davidson LAG, Fishman AP. The regulation of ventilation in diffuse pulmonary fibrosis. Am J Med 1965;38:199-216.

10 Snider GL, Doctor RL. The mechanics of ventilation in sarcoidosis. Am Rev Respir Dis 1964;89:897-908.
11 Young RC, Carr C, Shelton TG, Mann M, Ferrin A, Laurey FJR, Harden KA. Sarcoidosis: relationship between changes in lung structure and function. Am Rev Respir Dis 1966;95:224-38.

12 Marshall $R$, Karlish AJ. Lung function in sarcoidosis Thorax 1971;26:402-5.

13 Renzi G, Milic-Emili J, Grassino AE. The pattern of breathing in diffuse lung fibrosis. Bull Eur Physiopatho Respir 1982;18:461-72.

14 Gaensler EA, Carrington CB, Coutu RE, Fitzgerald MX. Radiographic, physiologic, pathologic correlations in interstitial pneumonias. Progress in Respiration Research 1974;8:223-41.

15 Gaensler EA, Carrington CB, Coutu RE, Tomasian A Hoffman L, Smith AA. Pathological, physiological and radiological correlations in the pneumoconioses. Ann $N Y$ radiological correlations in the

16 Goldberg M, Green SB, Moss ML, Marbach CB, Garfinke D. Computer-based instruction and diagnosis of acid-base disorders. JAMA 1973;223:269-75.

17 Javaheri S, Kazemi H. Metabolic alkalosis and hypoventilation in humans. Am Rev Respir Dis 1987;136:1011-6.

18 Itallie TBV. Health implications of overweight and obesity in the United States. Ann Intern Med 1985;103:983-8.

19 Gaensler EA, Macklem P, Cherniak R, Permutt S, Ferris B. Pulmonary function in epidemiology standardization project. Am Rev Respir Dis 1978;188:7-112.

20 Gaensler EA, Smith AA. Attachment for automated single breath diffusing capacity measurements. Chest 1973; 63:136-45.

21 Kori RC, Callahan R, Boren HG, Syner JC. The Veterans Administration-Army Cooperative Study of Pulmonary Function. I. Clinical spirometry in normal man. $A m \mathrm{~J} \mathrm{Med}$ 1961;30:243-58

22 Gilbert R, Auchincloss JH Jr, Brodsky J, Bowden W. Changes in tidal volume, frequency and ventilation induced by their measurement. $J$ Appl Physio 1972;33:252-4.

23 West JB. Causes of carbon dioxide retention in lung disease. N Engl J Med 1971;284:1232-6.

24 West JB. Assessing pulmonary gas exchange. N Engl J Med 1987;316:1336-8.

25 Kornbluth RS, Turino GM. Respiratory control in diffuse interstitial lung disease and diseases of the pulmonary vasculature. Clin Chest Med 1980;1:91-102.

26 Rebuck AS, Stulsky AS. Control of breathing in diseases of the respiratory tract and lungs. In: Fishman AP, ed. Handbook of physiology. Vol 2. The respiratory system. Bethesda, Maryland: American Physiological Society, 1986;771-91.

27 Guz A, Noble MIM, Eisele JH, Trenchard D. Experimenta results of vagal block in cardiopulmonary disease. In Porter R, ed. Breathing: Hering-Breuer centenary symposium. London: Churchill, 1970;17-40.

28 Guz A, Noble MIM, Eisele JH, Trenchard D. Experimental results of vagal bock in cardiopulmonary disease. In: Porter R, ed. Breathing: Hering-Breuer centenary symposium. London: Churchill, 1970;315-36.

29 Freedman S, Campbell EJM. The ability of normal subjects to tolerate added inspiratory loads. Respir Physiol to tolerate added

30 Bland S, Lazerou L, Dyck G, Cherniack RM. Influence of the "chest wall" on respiratory rate and depth. Respir Physiol 1967;3:47-54.

31 Agostoni E, D'Angelo E, Piolini M. Breathing pattern in men during inspiratory elastic loads. Respir Physiol 1978;34:279-393.

32 Pope H, Holloway R, Campbell EJM. The effects of elastic and resistive loading of inspiration on the breathing of conscious man. Respir Physiol 1968;4:363-72.

33 Remmers JE, Marttila I. Action of intercostal muscle afferents on the respiratory rhythm of anesthetized cats. Respir Physiol 1975;24:31-41.

34 Turner-Warwick $M$, Haslan PL. The value of serial bronchoalveolar lavages in assessing the clinical progess of patients with cryptogenic fibrosing alveolitis. Am Rev patients with cryptogenic
Respir Dis 1987;135:26-34.

35 Phillipson EA, Murphy E, Kozar LF, Schultze RK. Role of vagal stimuli in exercise ventilation in dogs with vagal stimuli in exercise ventilation in dogs with
experimental pneumonitis. $J$ Appl Physiol 1975;39:76-85.

36 Mead J. Control of respiratory frequency. J Appl Physio 1960;15:325-36.

37 Donahoe M, Rogers RM, Wilson DO, Pennock BE. Oxygen consumption of the respiratory muscles in normal and in malnourished patients with chronic obstructive pulmonary disease. Am Rev Respir Dis 1989;140:385-91.

38 Cala SJ, Wilcox P, Edyvean J, Rynn M, Engel LA. Oxygen cost of inspiratory loading: resistive $v$ elastic. $J$ App Physiol 1991;70:1983-90. 